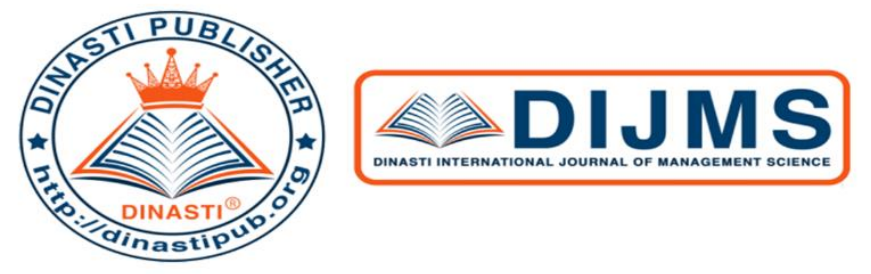

$$
\begin{array}{r}
+6281387654578 \\
+6281387654578 @
\end{array}
$$

https://dinastipub.org/DIJMS (8)

dinasti-info@gmail.com (๑)

THE REACTION OVER EMPLOYEES PERFORMANCE THROUGH

ORGANIZATIONAL CULTURE AND ORGANIZATIONAL COMMITMENT

VARIABLES WHOM MEDIATED BY ORGANIZATIONAL CITIZENSHIP

BEHAVIOUR AND ITS IMPLICATIONS AT PT SHARPRINDO DINAMIKA PRIMA

Dadan Sutrisno ${ }^{1}$, Chaeruddin ${ }^{2}$

1) Student of Magister Management in Mercu Buana University, Jakarta, Indonesia

${ }^{2)}$ Lecturer of Economy and Business in Mercu Buana University, Jakarta, Indonesia

ARTICLE INFORMATION

Received: $29^{\text {th }}$ April 2020

Revised: $29^{\text {th }}$ May 2020

Issued: $19^{\text {th }}$ July 2020

Corresponding author: first author

E-mail:

dadansutrisno91@gmail.com chaerudin18@gmail.com

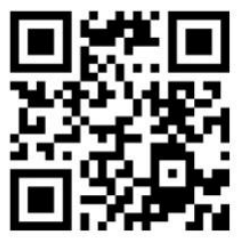

DOI:10.31933/DIJMS

\begin{abstract}
This research aims to inspects the reaction between Organizational Culture, Organizational Commitment and Organizational Citizenship Behavior also its implications to Employees Performance at PT Sharprindo Dinamika Prima Tangerang. By using 100 employees at PT Sharprindo Dinamika Prima as respondents, and samples would taking with using a random sampling design proportional strata. The Data has been processed by SmartPLS SEM Version 3.0. The results of this research was indicated that Organizational Culture has strong reaction towards Employees Performance, Organizational Commitment has strong reaction over Employee Performance, Organizational Citizenship Behavior has strong reactions over Employee Performance, the outcome from this research simultaneously shows that the Organizational Culture, Organizational Commitment and Organizational Citizenship Behavior simultaneously has positive react kon employee performance.

Keywords: Organizational Culture, Organizational Commitment, Organizational Citizenship Behavior, Employee Performance.
\end{abstract}

\title{
INTRODUCTION
}

In these recent era of globalization, an organizations in a company has develop it strictly in order to be able to compete with other companies in the country and abroad. Therefore, companies need quality of Human Resources in their work so that the company's goals would achieved. Every individual in the company is a human resource thats very important for the company because they have different social status both from the mind,sense, talent, creativity, attitude and energy that all needed to do the work given by the company so the differences would be a challenge for the company. 
This situation were also faced by PT Sharprindo Dinamika Prima, a manufacturing company for compressor machines, generators, waterpumps which located in Tangerang. In this era of globalization they are not only compete with local companies but must be able to compete with foreign companies aswell.

Table 1. Performance Assessment Report of PT Sharprindo Dinamika Prima's Employees

\begin{tabular}{|c|c|c|c|c|c|c|c|}
\hline \multirow{2}{*}{$\begin{array}{l}\text { Strategy } \\
\text { Objectives }\end{array}$} & \multirow{2}{*}{ KPI } & \multicolumn{3}{|c|}{2016} & \multicolumn{3}{|c|}{2017} \\
\hline & & Target & Reality & $(\%)$ & Target & Reality & $(\%)$ \\
\hline $\begin{array}{l}\text { Increasing on } \\
\text { assets and } \\
\text { quantity }\end{array}$ & $\begin{array}{l}\text { NPL } \\
\text { (Million } \\
\text { IDR) } \\
\end{array}$ & 889 & 1378 & $65,20 \%$ & 900 & 1272 & $74,67 \%$ \\
\hline $\begin{array}{l}\text { Improving } \\
\text { Product } \\
\text { Development } \\
\text { which oriented } \\
\text { to the Customer } \\
\text { Needs }\end{array}$ & $\begin{array}{l}\% \text { of } \\
\text { products } \\
\text { that meet } \\
\text { the target }\end{array}$ & $80 \%$ & $48 \%$ & $60 \%$ & $80 \%$ & $78,57 \%$ & $98,21 \%$ \\
\hline $\begin{array}{l}\text { Optimize sales } \\
\text { productivity } \\
\text { with Customer } \\
\text { Management }\end{array}$ & $\begin{array}{l}\% \text { of } \\
\text { marketing } \\
\text { employees } \\
\text { who } \\
\text { reached } \\
\text { the targets }\end{array}$ & $75 \%$ & $21,79 \%$ & $29,05 \%$ & $75 \%$ & $30,45 \%$ & $40,60 \%$ \\
\hline \multirow{2}{*}{$\begin{array}{c}\text { Strategy } \\
\text { Objectives }\end{array}$} & \multirow{2}{*}{ KPI } & \multicolumn{3}{|c|}{2018} & \multicolumn{3}{|c|}{2019} \\
\hline & & Target & Reality & $(\%)$ & Target & Reality & $(\%)$ \\
\hline $\begin{array}{l}\text { Increasing on } \\
\text { assets and } \\
\text { quantity }\end{array}$ & $\begin{array}{l}\text { NPL } \\
\text { (Million } \\
\text { IDR) } \\
\end{array}$ & 1180 & 2374 & $49.75 \%$ & 1250 & 2444 & $52,75 \%$ \\
\hline $\begin{array}{l}\text { Improving } \\
\text { Product } \\
\text { Development } \\
\text { which oriented } \\
\text { to the Customer } \\
\text { Needs }\end{array}$ & $\begin{array}{l}\% \text { of } \\
\text { products } \\
\text { that meet } \\
\text { the target }\end{array}$ & $80 \%$ & $57,14 \%$ & $71,43 \%$ & $80 \%$ & $58,20 \%$ & 73,45 \\
\hline $\begin{array}{l}\text { Optimize sales } \\
\text { productivity } \\
\text { with Customer } \\
\text { Management }\end{array}$ & $\begin{array}{l}\% \text { of } \\
\text { marketing } \\
\text { employees } \\
\text { who } \\
\text { reached } \\
\text { the targets }\end{array}$ & $75 \%$ & $29,75 \%$ & $39,67 \%$ & $75 \%$ & $30,75 \%$ & $40,30 \%$ \\
\hline
\end{tabular}

Source: HRD of PT Sharpindo Dinamika Prima (2019)

From the Table 1 it can be seen that from the performance evaluation indicators in terms of quantity the performance of PT Sharprindo Dinamika Prima employees continues to increase in quantity but in terms of percentage it was still experiencing the fluctuations. Which means that the company should continue to concentrate on improving the performance of its employees.

Table 2. Ratio of Troubled Employees at PT Sharpindo Dinamika Prima

\begin{tabular}{cccc}
\hline Year & $\begin{array}{c}\text { Number of } \\
\text { Warnings }\end{array}$ & $\begin{array}{c}\text { Number of } \\
\text { Employees }\end{array}$ & $\begin{array}{c}\text { Problematic } \\
\text { Employee Ratio }\end{array}$ \\
\hline $\mathbf{2 0 1 5}$ & 20 & 300 & $6,67 \%$ \\
$\mathbf{2 0 1 6}$ & 28 & 320 & $8,75 \%$ \\
$\mathbf{2 0 1 7}$ & 25 & 335 & $7,46 \%$ \\
$\mathbf{2 0 1 8}$ & 13 & 330 & $3,93 \%$ \\
$\mathbf{2 0 1 9}$ & 8 & 340 & $2,35 \%$ \\
\hline
\end{tabular}

Source: HRD of PT Sharpindo Dinamika Prima (2019)

From Table 2 it can be seen that the ratio of problem employees at PT Sharprindo Dinamika Prima continues to decrease, which means that the management is always evaluating ways to improve organizational performance for all employees in the hope of achieving company goals. This indicates that the company must always evaluate and develop ways that have been done before to continue to maintain and even improve the performance of employees itself. 
From the data that authors obtained, then conduct a pre research (survey) of 25 employees and conduct discussions with HRD \& GA Manager. The result was agreed in order to improve the employee performance one of way is developed the quality of Organizational Culture, with organizational commitment and OCB. Seeing those background above, the writer has interested to conducting the research with the title "The Reaction over those Organizational Culture and Organizational Commitment variables to Organizational Citizenship Behavior (OCB) And Its Implications towards the Employees Performance at PT. Sharprindo Dinamika Prima ".

\section{LITERATURE REVIEW}

\section{Organizational Culture}

Organizational culture is a system of values that are believed by all members of the organization, that culture has been studied, implemented and developed which functions as an adhesive system as a reference for the company in achieving its goals Raf et. al. (2014) in Rachmad (2016:18). According to Robbins and Judge (2015), organizational culture reflects a similar perception of the members at organization. Therefore, it is hoped that individuals who have different backgrounds or at different levels in the organization could understand the culture of the organization with similar understandings. Hosseini (2014) affirms that organizational culture can work as an operational system by directing employee behavior, stabilizing the orientation of the new organization and leading any changes in current or future.

\section{Organizational Commitment}

According to Kaswan (2012) in Raziyam et al (2017:3) Organizational Commitment was defined as an attitude that reflects employee loyalty to the organization and the ongoing process by which organizational members express concern for the organization and the success of sustainable progress fibers. According to Titik et. al. (2014:24) organizational commitment is an ability and willingness to align behavior with the needs, priorities and goals of the organization. According to Ivanevich et. al. (2007) describes the Organizational Commitment as a sense of identification with the goals of the organization, a feeling of being involved in the tasks of the organization and any care for the organization. Organizational Commitment has an important role, because it will show a sense of attachment that is appointed by employees to the organization. . Commitment to the organization means more than formal membership, because it includes an attitude of liking the organization and a willingness to strive for a high level of effort for the interests of the organization as an achievement of objectives.

\section{Organizational Citizenship Behavior}

Robins \& Judge (2015:27) has defines the citizenship behaviors as discretionary behaviors which is not part of the employee's formal job requirements, and contribute to the psychological and social environment at work. Aldag and Reschke (1997:4) stated that organizational citizenship behavior as a very large individual contribution that exceeds the demands of the role in the organization and achieve an excellent performance. Organ, et. al. 
(2006) in Kusumajati (2014:64) said that Organizational Citizenship Behavior (OCB) as freedom of individual behavior, which is indirectly or explicitly recognized by the reward system and contributes to the effectiveness and efficiency of organizational functions. Organizational Citizenship Behavior (OCB) as well as behavior and attitudes that could benefit the organization which cannot be grown on the basis of formal role obligations or by contract or recompensation forms.

\section{Employee Performance}

According to Mangkunegara (2015:67) employee performance is the result of quality and quantity of work achieved by an employee in carrying out their duties accordance to responsibilities that given to them. Performance as a value on series of employee behaviors that contribute, both positive and negative to organizational achievement (Colquitt, et. al., 2015). Meanwhile, according to Gibson et al (2012) in Ricardianto (2018: 68) employee performance is the work that has done by qualified employee to complete the work in organization so it would expected that goals can be achieved efficiently and effectively.

\section{Prior Research}

Research whom conducted by Darto, Setyadi and Hariyadi (2015) shows that organizational culture has positive and strong reaction towards OCB. Research whom conducted by Indrawati and Elmi (2019) has explains that organizational commitment has positive and strong reaction towards OCB. Research whom conducted by Suryadi and Aima (2019) shows that organizational culture has positive and strong reaction towards employee performance. But there has exist The different research whom conducted by Badawi, Wadji, and Chaeruddin (2017) which states that organizational culture does not affect employee performance. The other different research was from Pratama and Aima (2018) which said that organizational commitment does not affect to employee performance. Research conducted by Suzana (2017) also defined that OCB has positive and strong effect on employee performance. Research whom conducted by Nugraha and Adnyani (2018) explains that organizational culture and organizational commitment simultaneously reacted towards the OCB. Research whom conducted by Maulani, Widiartanto, and Dewi (2015) stated that organizational culture, organizational commitment and OCB simultaneously affect to the employee performance. This research also states that OCB could mediate the reaction between organizational culture and organizational commitment against the employee performance.

\section{Thinking Framework}

Based on these research theory and those prior research that mentioned above, the authors created some formulate for the thinking framework as follows: 


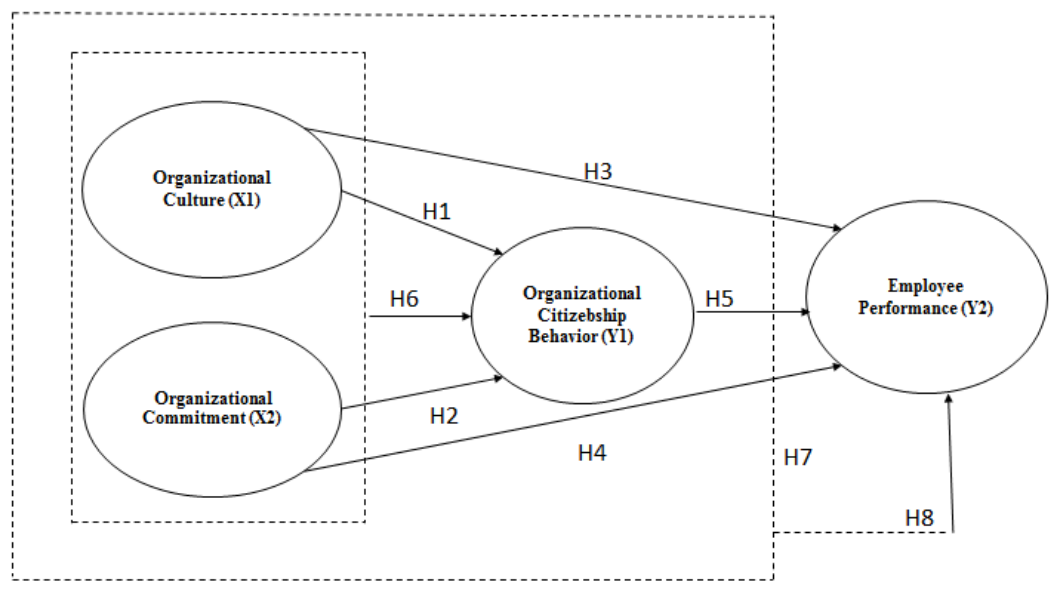

Picture 1. Thinking Framework

Source: Theory Study

\section{Hypothesis}

Based on the literature review and thinking framework that has been mentioned above, those following research hypothesis could be formulated as : 1) Organizational culture has strong reaction towards Organizational Citizenship Behavior (OCB), 2) Organizational commitment has a significant reaction towards Organizational Citizenship Behavior (OCB), 3) Cultural Culture organization has a strong reaction towards employee performance, 4) organizational commitment has a significant reaction over employee performance, 5) Organizational Citizenship Behavior (OCB) has a significant influence on employee performance, 6) Organizational culture and organizational commitment togetherness have a significant reactions over Organizational Citizenship Behavior (OCB), 7) Organizational culture, organizational commitment, alongside Organizational Citizenship Behavior (OCB) togetherness have a significant reactions over employee performance, and 8) Organizational Citizenship Behavior (OCB) directly mediates organizational culture and organizational commitment to employee performance range.

\section{RESEARCH METHODS}

This kind of research is quantitative research by using primary data and secondary data. The researcher created this research to make it easily understand, explain and analyze all the correlation between independent variables and dependent variable, which in the research would be analyzed by relevant statistical data to test those hypothesis.

The independent variables in this research has divided into Organizational Culture $\left(\mathrm{X}_{1}\right)$, Organizational Commitment $\left(\mathrm{X}_{2}\right)$, while the dependent variables were Organizational Citizenship Behavior (Z) and Employee Performance (Y). The subjects were permanent employees at PT Sharprindo Dinamika Prima.

The research population was set and limited to only permanent employees totaling 134 (one hundred thirty-four) people based on employee data in May 2019. But These Samples who qualified in this research only 100 people (Slovin, 5\% error tolerance). Whereas using Probability Sampling as technique with proportional stratified random sampling design.

The data analysis techniques using SmartPLS version 3.0 software which run on computer media. PLS (Partial Least Square) is a variance-based structural equation analysis 
(SEM) that can simultaneously test those measurement models alongside its structural model testing. The measurement model aim to test the validity and reliability, while the structural model used to test causality (hypothesis testing with predictive models).

\section{FINDINGS AND DISCUSSION}

\section{Outer Model Test}

Those Evaluation of convergent validity from checking individual item reliability that could be seen from the standardizef loading factor value. Standardizef loading factor was illustrates the magnitude of the correlation between each measurement item (indicator) and its construct. The loading factor value based on this research is $>0.5$ so if the loading factor value is $<0.5$, the indicators could be excluded from the model.

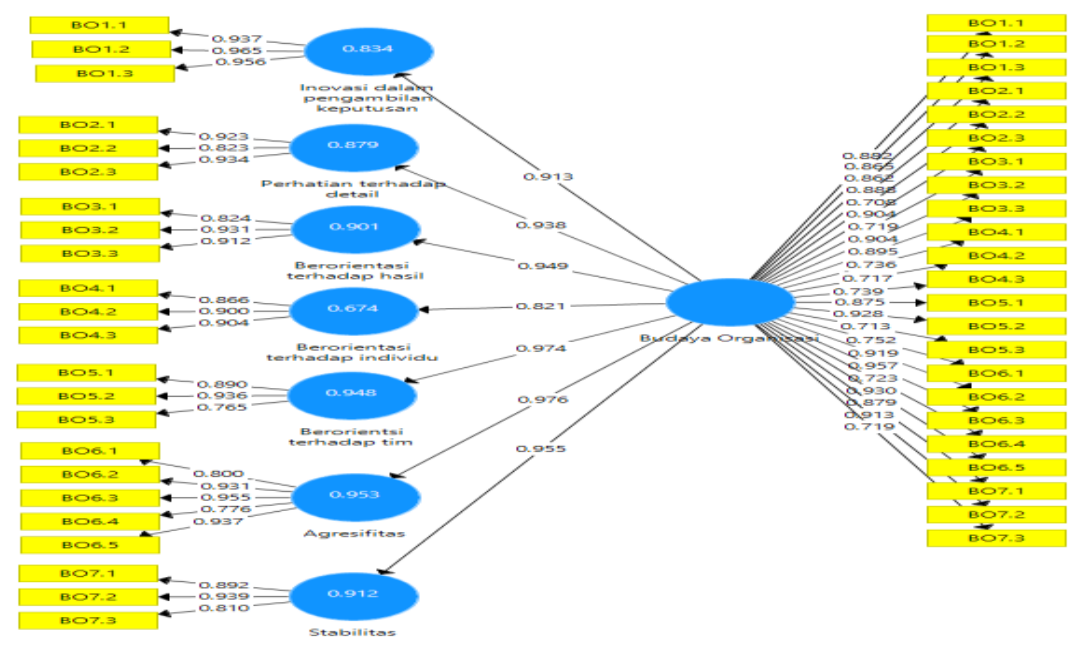

Picture 2. Calculation Results over the Outer Model of Organizational Culture Source: Smart PLS versi 3.2.8

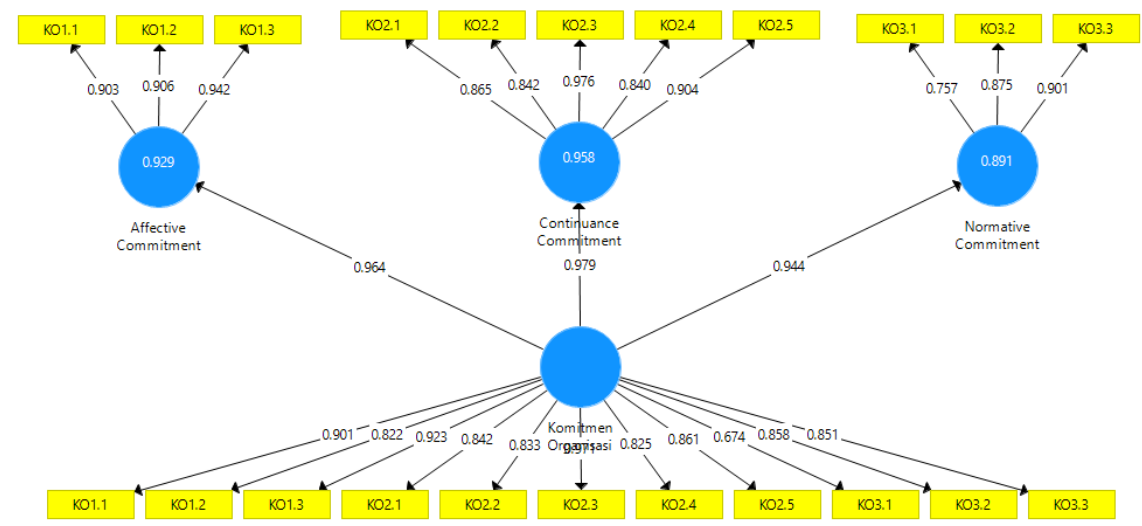

Picture 3. Calculation Results over Outer Model of Organizational Commitment Source: Smart PLS versi 3.2.8 


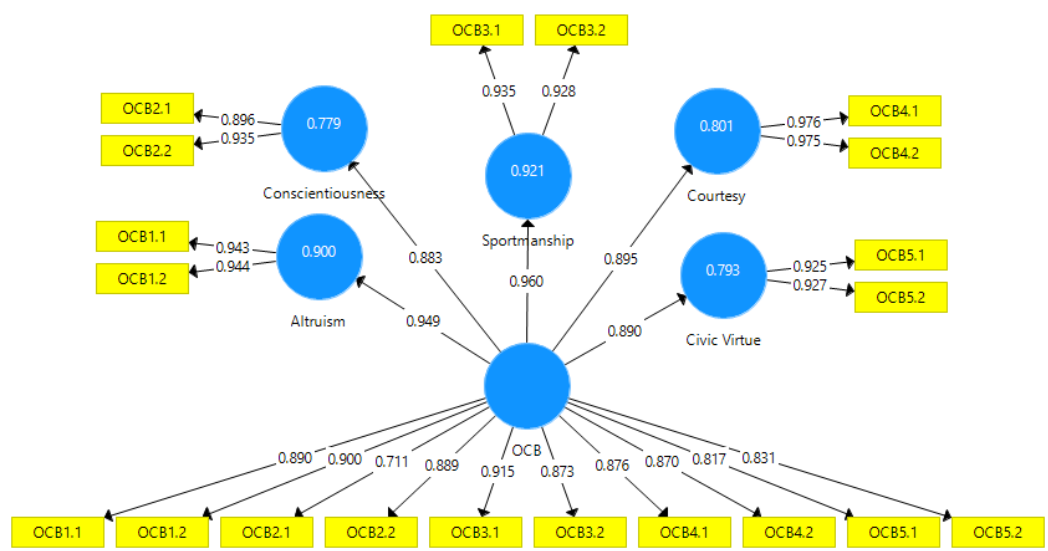

Picture 4. Calculation Results over Outer Model of Organizational Citizenship Behaviour Source: Smart PLS versi 3.2.8

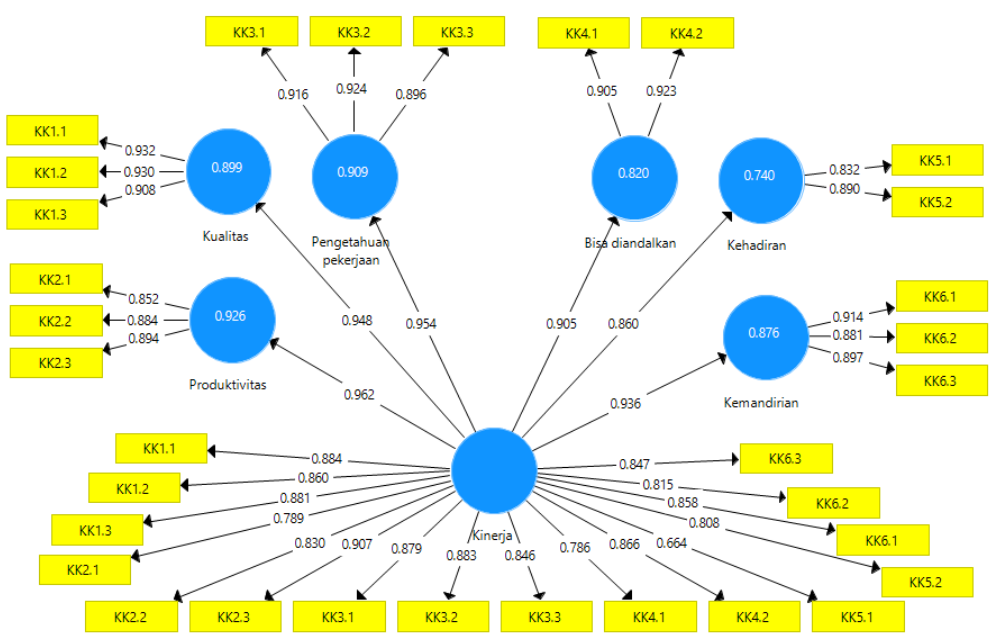

Picture 5. Calculation Results over Outer Model of Employee Performance

Source: Smart PLS versi 3.2.8

From these convergent validity results by SmartPLS version 3.2.8 had shown through Figure 2 until Figure 5 it stated that the indicators on organizational culture variables, organizational commitment, OCB and employee performance have a loading factor $>0.5$, so that all indicators were declared valid and still used in the model or not removed from the model.

Table 3. Cronbach's Alpha Value and Composite Reliability Value

\begin{tabular}{lccccc}
\hline \multicolumn{1}{c}{ Variable } & $\begin{array}{c}\text { Composite } \\
\text { Reliability }\end{array}$ & Term & $\begin{array}{c}\text { Cronbach's } \\
\text { Alpha }\end{array}$ & Term & Information \\
\hline Organizational Culture $\left(\mathrm{X}_{1}\right)$ & 0,981 & $>0,7$ & 0,980 & $>0,6$ & Reliable \\
\hline Organizational Commitment $\left(\mathrm{X}_{2}\right)$ & 0,967 & $>0,7$ & 0,962 & $>0,6$ & Reliable \\
\hline OCB $(\mathrm{Z})$ & 0,966 & $>0,7$ & 0,960 & $>0,6$ & Reliable \\
\hline Employee Performance $(\mathrm{Y})$ & 0,974 & $>0,7$ & 0,972 & $>0,6$ & Reliable \\
\hline
\end{tabular}

Source: Smart PLS versi 3.2.8

Through the Table 3 it is seen that the Cronbach's Coefficient Alpha value for organizational culture variables, organizational commitment, OCB and employee performance $>0.7$ and Composite reliability value $>0.7$, so all variables were declared reliable. 


\section{Inner Model Test}

To evaluate those value of the path coefficient, based on the calculation from SmartPLS version 3.2.8 bootstrapping the path coefficient results obtained and illustrates the strength of connection between constructs / variables as shown in Table 4 below.

Table 4. Path Coefficient and P-Values (Direct and Indirect Reacted )

\begin{tabular}{|c|c|c|c|c|c|}
\hline Variable & $\begin{array}{l}\text { Original } \\
\text { Sample } \\
(\mathbf{O}) \\
\end{array}$ & $\begin{array}{c}\text { Mean } \\
\text { Sample } \\
(\mathrm{M}) \\
\end{array}$ & $\begin{array}{l}\text { Standard } \\
\text { Deviation } \\
\text { (STDEV) } \\
\end{array}$ & $\begin{array}{c}\text { T Statistics } \\
\text { (O/STDEV) }\end{array}$ & $\begin{array}{c}\mathbf{P} \\
\text { Values }\end{array}$ \\
\hline \multicolumn{6}{|c|}{ Direct Influence } \\
\hline $\begin{array}{l}\text { Organizational Culture }\left(\mathrm{X}_{1}\right) \\
\text { Employee Performance }(\mathrm{Y})\end{array}$ & 0.385 & 0.357 & 0.071 & 2.732 & 0.003 \\
\hline $\begin{array}{l}\text { Organizational Culture }\left(\mathrm{X}_{1}\right)-> \\
\text { OCB }(\mathrm{Z})\end{array}$ & 0.624 & 0.597 & 0.063 & 4.214 & 0.000 \\
\hline $\begin{array}{l}\text { Organizational Commitment }\left(\mathrm{X}_{2}\right) \\
->\text { Employee Performance }(\mathrm{Y})\end{array}$ & 0.330 & 0.361 & 0.074 & 2.599 & 0.005 \\
\hline $\begin{array}{l}\text { Organizational Commitment }\left(\mathrm{X}_{2}\right) \\
\text {-> OCB }(\mathrm{Z})\end{array}$ & 0.331 & 0.357 & 0.058 & 2.310 & 0.011 \\
\hline $\begin{array}{l}\text { OCB }(\mathrm{Z}) \text {-> Employee } \\
\text { Performance }(Y)\end{array}$ & 0.286 & 0.284 & 0.063 & 4.038 & 0.000 \\
\hline \multicolumn{6}{|c|}{ Indirect Influence } \\
\hline $\begin{array}{l}\text { Organizational Culture }\left(\mathrm{X}_{1}\right)-> \\
\text { OCB }(\mathrm{Z}) \text {-> Employee } \\
\text { Performance }(\mathrm{Y})\end{array}$ & 0.179 & 0.171 & 0.061 & 2.295 & 0.002 \\
\hline $\begin{array}{l}\text { Organizational Commitment }\left(\mathrm{X}_{2}\right) \\
\text {-> OCB }(\mathrm{Z}) \text {-> Employee } \\
\text { Performance }(\mathrm{Y})\end{array}$ & 0.095 & 0.100 & 0.044 & 2.151 & 0.016 \\
\hline
\end{tabular}

\section{Source: Smart PLS versi 3.2.8}

There has significant reaction if the significance value is below than 0.05 . The results concluded which could provide is:

1) Organizational culture has strong . impact towards performance with coefficient of 0.385 . T-Statistic value is 2.732 and $\mathrm{P}-$ Values is 0.003 (significance less than 0.05 ). The coefficient value is positive, which means that the organizational culture variable $\left(\mathrm{X}_{1}\right)$ has positive reaction on performance variable (Y).

2) Organizational culture has strong impact towards organizational citizenship behavior with coefficient of 0.624 . T-Statistic value is 4,214 and P-Values is 0,000 (significance is less than 0.05 ). The coefficient value is positive, that is equal to 0.624 meaning that the organizational culture variable $\left(\mathrm{X}_{1}\right)$ has a positive reaction over organizational citizenship behavior (Z).

3) Organizational commitment has strong reaction towards performance with a coefficient of 0.330. T-Statistic value is 2,599 and P-Values is 0,005 (significance less than 0.05). The coefficient value is positive, which is equal to 0.330 meaning that organizational commitment variable $\left(\mathrm{X}_{2}\right)$ has a positive reaction over the performance variable $(\mathrm{Y})$.

4) Organizational commitment has strong impact on organizational citizenship behavior with a coefficient of 0.331 . T-Statistic value is 2,310 and P-Values is 0,011 (significance less than 0.05). The coefficient value is positive and equal to 0.331 which means that the 
organizational commitment variable $\left(\mathrm{X}_{2}\right)$ has a positive reaction over organizational citizenship behavior variable $(\mathrm{Z})$.

5) Organizational citizenship behavior has strong impact on performance with a coefficient of 0.286. T-Statistic value is 4,038 and P-Values is 0,000 (significance less than 0.05). The coefficient value is positive and equal to 0.286 which means that the variable of organizational citizenship behavior $(\mathrm{Z})$ has a positive reaction over performance variable (Y).

6) There has an indirect influence of organizational culture variables on performance whom mediated by organizational citizenship behavior with a coefficient of 0.179 . T-Statistic value is 2,925 and P-Values is 0,002 (significance less than 0.05 ). The coefficient value is positive, which means that an increase in organizational citizenship behavior will increase the influence of organizational culture variables towards performance variables and if a decrease in organizational citizenship behavior will reduce the influence of organizational culture variables on performance variables.

7) There has an indirect reactions towards organizational commitment variables on performance whom mediated by organizational citizenship behavior with a coefficient of 0.095. T-Statistic value is 2,151 and P-Values is 0,016 (significance less than 0.05). The coefficient value is positive, which means that an increase in organizational citizenship behavior will increase the reaction of organizational commitment variables on performance variables and if a decrease in organizational citizenship behavior will reduce the effect of organizational commitment variables on performance variables.

\section{$\mathbf{R}^{2}$ Evaluation dan F Statistic Test}

To asses the value of $\mathrm{R}^{2}$ based on the calculation results using calculate from SmartPLS version 3.2.8 algorithm, the results of the $\mathrm{R}^{2}$ value are 0.833 for organizational citizenship behavior variables and 0.899 for employee performance variables. The value of R2 shows that the level of determination of exogenous variables (Organizational Culture and Organizational Commitment) towards the endogenous is quite high. The simultaneous reaction could be done by calculating the $\mathrm{F}$ arithmetic / F statistic using these formula.

1) $R^{2}=0,833(Z)$

$$
\mathrm{F} \text { count }=\frac{\frac{R^{2}}{(k-1)}}{1-R^{2} /(n-k)}=\frac{\frac{0.833}{(3-1)}}{1-0,833 /(100-3)}=\frac{0.417}{0.002}=241.92
$$

2) $\mathrm{R}^{2}=0,899(\mathrm{Y})$

$\mathrm{F}$ count $=\frac{\frac{R^{2}}{(k-1)}}{1-R^{2} /(n-k)}=\frac{\frac{0.899}{(4-1)}}{1-0,899 /(100-4)}=\frac{0.300}{0.001}=284.83$

From those results calculation above it can be seen that the F count value of 1 in this research was 241.92 so it was evident that the organizational culture variable, organizational commitment together had a positive and significant influence on OCB. While the calculated F count value 2 in this research was 248.83, so the organizational culture variables, organizational commitment, and OCB together had a positive and significant effect on employee performance.

\section{Correlation Between Dimensions}

To examine the correlation between dimensions, those variable correlation of organizational culture dimensions and organizational commitment to organizational citizen 
behavior were obtained all dimensions have a strong influence to organizational citizen behavior and employee performance.

\section{Table 5. Result of Correlation Between Dimensions}

\begin{tabular}{|c|c|c|c|c|c|c|c|c|c|c|}
\hline \multirow[t]{2}{*}{ Dimension/Variable } & \multicolumn{2}{|c|}{$\begin{array}{c}\text { Altruism } \\
\text { (Z.1) }\end{array}$} & \multicolumn{2}{|c|}{$\begin{array}{c}\text { Conscientiousness } \\
\text { (Z.2) }\end{array}$} & \multicolumn{2}{|c|}{$\begin{array}{c}\text { Sportmanship } \\
\text { (Z.3) }\end{array}$} & \multicolumn{2}{|c|}{$\begin{array}{c}\text { Courtesy } \\
(\mathrm{Z} .4)\end{array}$} & \multicolumn{2}{|c|}{$\begin{array}{c}\text { Civic } \\
\text { Virtue(Z.5) }\end{array}$} \\
\hline & $\mathbf{r}$ & Sig. & $\mathbf{r}$ & Sig. & $\mathbf{r}$ & Sig. & $\mathbf{r}$ & Sig. & $\mathbf{r}$ & Sig. \\
\hline $\begin{array}{l}\text { Innovation in decision } \\
\text { making (X1.1) }\end{array}$ & 0.834 & 0.000 & 0.765 & 0.000 & 0.812 & 0.000 & 0.675 & 0.000 & 0.816 & 0.000 \\
\hline $\begin{array}{l}\text { Giving attention to the } \\
\text { details (X1.2) }\end{array}$ & 0.749 & 0.000 & 0.762 & 0.000 & 0.786 & 0.000 & 0.652 & 0.000 & 0.707 & 0.000 \\
\hline $\begin{array}{l}\text { Results oriented } \\
\text { (X1.3) }\end{array}$ & 0.743 & 0.000 & 0.757 & 0.000 & 0.758 & 0.000 & 0.620 & 0.000 & 0.755 & 0.000 \\
\hline $\begin{array}{l}\text { Individual oriented } \\
\text { (X1.4) }\end{array}$ & 0.651 & 0.000 & 0.741 & 0.000 & 0.689 & 0.000 & 0.519 & 0.000 & 0.621 & 0.000 \\
\hline Team oriented (X1.5) & 0.771 & 0.000 & 0.783 & 0.000 & 0.805 & 0.000 & 0.629 & 0.000 & 0.751 & 0.000 \\
\hline Aggressiveness (X1.6) & 0.813 & 0.000 & 0.816 & 0.000 & 0.850 & 0.000 & 0.729 & 0.000 & 0.770 & 0.000 \\
\hline Stability (X1.7) & 0.756 & 0.000 & 0.806 & 0.000 & 0.779 & 0.000 & 0.700 & 0.000 & 0.708 & 0.000 \\
\hline $\begin{array}{l}\text { Affective } \\
\text { Commitment (X2.1) }\end{array}$ & 0.722 & 0.000 & 0.696 & 0.000 & 0.775 & 0.000 & 0.629 & 0.000 & 0.678 & 0.000 \\
\hline $\begin{array}{l}\text { Continuance } \\
\text { Commitment (X2.2) }\end{array}$ & 0.794 & 0.000 & 0.696 & 0.000 & 0.815 & 0.000 & 0.668 & 0.000 & 0.751 & 0.000 \\
\hline $\begin{array}{l}\text { Normative } \\
\text { Commitment (X2.3) }\end{array}$ & 0.710 & 0.000 & 0.655 & 0.000 & 0.774 & 0.000 & 0.633 & 0.000 & 0.663 & 0.000 \\
\hline
\end{tabular}

\begin{tabular}{|c|c|c|c|c|c|c|c|c|c|c|c|c|}
\hline \multirow[t]{2}{*}{ Dimension/Variable } & \multicolumn{2}{|c|}{$\begin{array}{c}\text { Quality } \\
\text { (Y.1) }\end{array}$} & \multicolumn{2}{|c|}{$\begin{array}{c}\text { Productivity } \\
\text { (Y.2) }\end{array}$} & \multicolumn{2}{|c|}{$\begin{array}{c}\text { Work } \\
\text { Knowledge } \\
\text { (Y.3) }\end{array}$} & \multicolumn{2}{|c|}{$\begin{array}{c}\text { Reliability } \\
\text { (Y.4) }\end{array}$} & \multicolumn{2}{|c|}{$\begin{array}{c}\text { Absenteeism } \\
\text { (Y.5) }\end{array}$} & \multicolumn{2}{|c|}{$\begin{array}{c}\text { Independency } \\
\text { (Y.6) }\end{array}$} \\
\hline & $\mathbf{r}$ & Sig. & $\mathbf{r}$ & Sig. & $\mathbf{r}$ & Sig. & $\mathbf{r}$ & Sig. & $\mathbf{r}$ & Sig. & $\mathbf{r}$ & Sig. \\
\hline $\begin{array}{l}\text { Innovation in decision } \\
\text { making (X1.1) }\end{array}$ & 0.771 & 0.000 & 0.806 & 0.000 & 0.818 & 0.000 & 0.785 & 0.000 & 0.675 & 0.000 & 0.834 & 0.000 \\
\hline $\begin{array}{l}\text { Giving attention to the } \\
\text { details (X1.2) }\end{array}$ & 0.769 & 0.000 & 0.816 & 0.000 & 0.760 & 0.000 & 0.810 & 0.000 & 0.818 & 0.000 & 0.849 & 0.000 \\
\hline Results oriented (X1.3) & 0.763 & 0.000 & 0.774 & 0.000 & 0.763 & 0.000 & 0.751 & 0.000 & 0.762 & 0.000 & 0.811 & 0.000 \\
\hline $\begin{array}{l}\text { Individual oriented } \\
\text { (X1.4) }\end{array}$ & 0.657 & 0.000 & 0.714 & 0.000 & 0.627 & 0.000 & 0.734 & 0.000 & 0.637 & 0.000 & 0.705 & 0.000 \\
\hline Team oriented (X1.5) & 0.772 & 0.000 & 0.797 & 0.000 & 0.764 & 0.000 & 0.778 & 0.000 & 0.784 & 0.000 & 0.793 & 0.000 \\
\hline Aggressiveness (X1.6) & 0.790 & 0.000 & 0.828 & 0.000 & 0.802 & 0.000 & 0.802 & 0.000 & 0.740 & 0.000 & 0.833 & 0.000 \\
\hline Stability (X1.7) & 0.746 & 0.000 & 0.811 & 0.000 & 0.737 & 0.000 & 0.787 & 0.000 & 0.698 & 0.000 & 0.831 & 0.000 \\
\hline $\begin{array}{l}\text { Affective Commitment } \\
\text { (X2.1) }\end{array}$ & 0.752 & 0.000 & 0.806 & 0.000 & 0.757 & 0.000 & 0.749 & 0.000 & 0.751 & 0.000 & 0.784 & 0.000 \\
\hline $\begin{array}{l}\text { Continuance } \\
\text { Commitment (X2.2) }\end{array}$ & 0.806 & 0.000 & 0.842 & 0.000 & 0.820 & 0.000 & 0.787 & 0.000 & 0.769 & 0.000 & 0.836 & 0.000 \\
\hline $\begin{array}{l}\text { Normative } \\
\text { Commitment (X2.3) }\end{array}$ & 0.689 & 0.000 & 0.748 & 0.000 & 0.672 & 0.000 & 0.720 & 0.000 & 0.749 & 0.000 & 0.755 & 0.000 \\
\hline Altruism(Z.1) & 0.822 & 0.000 & 0.835 & 0.000 & 0.834 & 0.000 & 0.798 & 0.000 & 0.701 & 0.000 & 0.831 & 0.000 \\
\hline Conscientiousness(Z.2) & 0.695 & 0.000 & 0.788 & 0.000 & 0.678 & 0.000 & 0.727 & 0.000 & 0.593 & 0.000 & 0.725 & 0.000 \\
\hline Sportmanship (Z.3) & 0.799 & 0.000 & 0.890 & 0.000 & 0.794 & 0.000 & 0.794 & 0.000 & 0.698 & 0.000 & 0.829 & 0.000 \\
\hline Courtesy(Z.4) & 0.736 & 0.000 & 0.815 & 0.000 & 0.699 & 0.000 & 0.733 & 0.000 & 0.552 & 0.000 & 0.726 & 0.000 \\
\hline Civic Virtue(Z.5) & 0.763 & 0.000 & 0.738 & 0.000 & 0.805 & 0.000 & 0.731 & 0.000 & 0.704 & 0.000 & 0.744 & 0.000 \\
\hline
\end{tabular}

\section{Discussions}

Source: Smart PLS versi 3.2.8

There has significant impact of organizational culture on organizational citizenship behavior at PT. Sharprindo Dinamika Prima. Organizational culture has a positive effect on organizational citizenship behavior so it can be interpreted as a positive influence or the more 
increase on organizational culture, organizational citizenship behavior will also increase and vice versa. Its accordance to research whom conducted by Darto, Setyadi and Hariyadi (2015).

There has strong influence of organizational commitment to Organizational Citizenship Behavior at PT. Sharprindo Dinamika Prima. Organizational commitment variable has a positive reacted over organizational citizenship behavior so it can be interpreted as a positive influence or the more increase on organizational commitment, organizational citizenship behavior will also increase and vice versa. This accordance to research whom conducted by Indrawati and Elmi (2019).

There has strong reaction over Organizational Culture to Employees Performance at PT. Sharprindo Dinamika Prima. Organizational culture variables have a positive impact towards it so it can be interpreted as a positive influence or the more increase on organizational culture, it would affect he performance aswell and vice versa. This is in line with research whom conducted by Suryadi and Aima (2019).

There has strong reaction over organizational commitment to performance at PT. Sharprindo Dinamika Prima. Organizational commitment variable has shown a positive impact towards it so it can be interpreted as a positive influence or when there has an increase on organizational commitment, the performance will also increase and vice versa. This is according to prior research whom conducted by Pratama and Aima (2018).

There has strong reaction over organizational citizenship behavior on performance at PT. Sharprindo Dinamika Prima. These variable has a positive impact towards it so it can be interpreted as a positive influence or the more an increase on organizational citizenship behavior so the performance will also increase and vice versa. This accordancing to research whom conducted by Suzana (2017).

There has simultaneous effect of organizational culture and organizational commitment to organizational citizenship behavior. Organizational culture variables and organizational commitment could be influence the organizational citizenship behavior around 0.833 or 83.3\%. The Original sample was positive so $\mathrm{H}_{0}$ was rejected. This is in line with research whom conducted by Nugraha and Adnyani (2018).

There is a simultaneous influence of organizational culture and organizational commitment, and organizational citizenship behavior on performance. Variable organizational culture and organizational commitment, OCB is able to influence performance by 0.899 or $89.9 \%$. Original sample is positive so $\mathrm{H}_{0}$ is rejected. This is in accordance with research conducted by Maulani, Widiartanto, and Dewi (2015).

There has an indirect effect of organizational culture variables and organizational commitment to performance which mediated by organizational citizenship behavior towards performance at PT. Sharprindo Dinamika Prima. This accordance with research whom conducted by Maulani, Widiartanto, and Dewi (2015).

\section{CONCLUSION AND SUGGESTION Conclusions}

Based on these research results on employees performance at PT. Sharprindo Dinamika Prima, the following conclusions could be given as its below: 
1) There has significant impact of organizational culture on organizational citizenship behavior at PT. Sharprindo Dinamika Prima.

2) There has significant impact of organizational commitment to Organizational Citizenship Behavior at PT. Sharprindo Dinamika Prima.

3) here has a strong reaction over Performance through Organizational culture at PT. Sharprindo Dinamika Prima.

4) There has strong reactions over performance through organizational commitment at PT. Sharprindo Dinamika Prima.

5) There has strong reaction over organizational citizenship behavior on performance at PT. Sharprindo Dinamika Prima.

6) There has simultaneous effect from organizational culture and organizational commitment to organizational citizenship behavior.

7) There has simultaneous connections between organizational culture and organizational commitment, and organizational citizenship behavior on performance.

8) There has indirect effect of organizational culture variables and organizational commitment to performance whom mediated by organizational citizenship behavior at PT. Sharprindo Dinamika Prima.

\section{Suggestions}

According to research results against the employees performance at PT. Sharprindo Dinamika Prima, there could be given several advices like its follows:

1) Organizational Citizenship Behavior increases work productivity.

a) Employees who encourage other coworkers to speed up the completion of their coworkers' tasks and in turn to increase the productivity of these colleagues.

b) On time passing by the helpful behavior exhibited by employees will help spread best practice to all work units or groups.

2) Organizational Citizenship Behavior increases manager productivity.

a) Employees who display civic virtue behavior will help managers to get valuable advice or feedback from the employee to increase the effectiveness of the work unit.

b) Polite employees, who avoid conflicts with coworkers, will help managers avoid management crises.

3) Organizational Citizenship Behavior would saves the resources of management and the organization as a whole.

a) If employees help one another to solving problems in a job so there's no need to added the manager, the manager can consequently use his time to do the other tasks, such as creating plans.

b) Employees who has a high conscentiousness only need a minimal attentions from managers so the managers can delegate those greater responsibility to them, this means that more free time for managers to carry out another duty which is more important.

c) Old employees who help new employees in training and work orientation will help the organization reduce costs for these needs.

d) Employees who shown sportmanship behavior create a great help for managers not to spend too much time dealing with minor complaints by employees 
4) Organizational Citizenship Behavior helps save energy from scarce resources to maintain group functions.

a) The advantage of helping behavior is to increase spirits, morale, and group closeness, so the group members or managers do not need to spend energy and time to maintaining group functions.

b) Employees who display courtesy behavior towards coworkers will reduce conflicts in the group, so the time that spent on resolving management conflicts is reduced.

5) Organizational Citizenship Behavior can be an effective stuff for coordinating work group activities.

a) Displaying civic virtue behavior (such as attending and actively participating in meetings in work unit) will help coordination among group members, which last potentially increasing group effectiveness and efficiency.

b) Showing the courtesy behavior (eg sharing information about work with members of other teams) will avoiding the problems that require time and effort to solve.

6) Organizational Citizenship Behavior enhances the organization's ability to attract and retain the best employees.

a) Helpful behavior could increase morale and closeness and feeling of mutual belonging among group members, so it would improve organizational performance and help the organization to attract and retain good employees.

b) Giving examples to other employees by showing the sportsmanship behavior (for example not complaining because of small problems) will foster loyalty and commitment to the organization.

7) Organizational Citizenship Behavior increases organizational performance stability.

a) Helping employees who were absent at work or who have heavy workloads will increase stability (by reducing variability) of work unit performance.

b) Conscientiousness employees tend to retain consistently high levels of performance, thereby reducing variability in work unit performance.

8) Organizational Citizenship Behavior increases the ability of organizations to adapt with changing environments.

a) Employees who have a close connection with the market voluntarily provide information about changes which occur in the environment and provide advice on how to respond to these changes, so the organization could adapt quickly.

b) Employees who actively attend and participate in meetings in organization would help to disseminate information that is important and must be known by the organization.

c) Employees who showing the conscientiousness behavior (eg willingness to assume new responsibilities and learn new skills) would increase the ability of organization to adapt with changes that occur on its environment.

\section{REFERENCE}

Colquitt. Jason. A, Lepine. Jeffery. A dan Wesson. Michael. J. (2015). Organizational Behavior, $4^{\text {th }} \mathrm{ed}$. McGraw - Hill Education, United States of America. 
Darto, Mariman, Djoko Setyadi, dan Sukisno S. Riadi Sugeng Hariyadi. (2015). The Effect of Transformational Leadership, Religiosity, Job Satisfaction, and Organizational Culture on Organizational Citizenship Behavior and Employee Performance in the Regional Offices of National Institute of Public Administration, Republic of Indonesia. European Journal of Business and Management, Vol. 7, No.23.

Hosseini, Seyed AbdolRasoul. (2014). Components of Organizational Culture Based on Denison Model. Kuwait Chapter Of Arabian Journal Of Business And Management Review. 3 (12a): 31-42.

Indrawati, Maya Dwi dan Farida Elmi. (2019). Effect of Transformational Leadership, Organizational Commitments and Job Satisfaction on Organization Citizenship Behavior (OCB) at the Directorate of Primary School Development Ministry of Education and Culture. International Journal of Innovative Science and Research Technology, Vol. 4, Issue 9.

Ivancevich, John M., Robert Konopaske, Michael T. Matteson. (2007). Perilaku dan Manajemen Organisasi. Jil. 1. Jakarta: Erlangga.

Kusumajati, D.A. (2014). Organizational Citizenship Behavior (OCB) Karyawan pada Perusahaan. Humaniora, 5 (1), 62-70.

Mangkunegara, Anwar Prabu. (2016). Manajemen Sumber Daya Manusia Perusahaan. Bandung : PT. Remaja Rosdakarya.

Maulani, Venty Hertina, Widiartanto, Reni Shinta Dewi (2015). Pengaruh Budaya Organisasi dan Komitmen Organisasi Terhadap Kinerja Karyawan Melalui Organizational Citizenship Behavior (OCB) Sebagai Variabel Intervening (Studi Kasus Pada Karyawan Pt Masscom Graphy Semarang). Jurnal Ilmu Administrasi Bisnis, Vol. 4, No.3.

Nugraha, I Putu Satya dan I Gusti Ayu Dewi Adnyani. (2018). Pengaruh Budaya Organisasi, Komitmen Organisasi, dan Kompetensi Terhadaporganizational Citizenship Behaviour Pada Setda Kota Denpasar. E-Jurnal Manajemen Unud, Vol. 7, No. 1, PP: 1-28.

Pratama, Rizky dan M. Havidz Aima. (2018). The Effect of Compensation and Employee Engagement on Organizational Commitments and Its Implementation Toward Employee's Performance of PT XYZ Jakarta. International Journal of Scientific and Research Publications, Vol.8, Issue 12.

Pathan, Raziyam Dwi, Syahir Natsirm dan Harnida Wahyuni Adda. (2017). Analisis Pengaruh Komitmen Afektif, Komitmen Berkelanjutan dan Komitmen Normatif Terhadap Kinerja Karyawan pada PT Radio Nabula Nada di Kota Palu. Jurnal Ilmu Manajemen Universitas Tadulako, Vol. 3, No. 1.

Ricardianto, Prasadja (2018). Human Capital Management. Jakarta: Media.

Robbins, S. P \& Judge, T.A. (2015). Perilaku Organisasi. Jakarta: Salemba Empat.

Saluy, Ahmad Badawi, M. Farid Wadji, dan Chaeruddin. (2018). Pengaruh Kompetensi Guru Budaya Organisasi dan Iklim Kerja Terhadap Kinerja Guru (Studi Kasus SMK Sandikta Pondok Melati Bekasi). Jurnal Ilmiah Manajemen dan Bisnis Indikator, Vol 2, No.3.

Suryadi, Handy dan Muhammad Havidz Aima. (2019). The Influence of Organizational Culture and Training on Organizational Commitment and Also Its Implications on The 
Performance of Health Workers in Puskesmas Johar Baru District. Dinasti International Journal of Management Science, Vol. 1, Issue 1.

Suzana, Anna. (2017). Pengaruh Organizational Citizenship Behavior (OCB) Terhadap Kinerja Karyawan (Studi di: PT. Taspen (Persero) Kantor Cabang Cirebon). Jurnal Logika. Vol. XIX, No. 1A. 